AGRARIS: Journal of Agribusiness and Rural Development Research

Vol. 6 No. 1 January-June 2020

Article History:

Submitted : September $20^{\text {th }}, 2019$

Accepted : June $18^{\text {th }}, 2020$
Amam $^{1 *}$, Mochammad Wildan Jadmiko², Pradiptya Ayu Harsita ${ }^{3}$ Department of Animal Husbandry, Faculty of Agriculture, Universitas Jember

*) Correspondence email: amam.faperta@unej.ac.id

\title{
Institutional Performance of Dairy Farmers and The Impacts on Resources
}

\author{
DOI: https://doi.org/10.18196/agr.6191
}

\begin{abstract}
Farmers institution is an organization that allows farmers to carry out farm agribusiness activities, from upstream (input) to downstream (processing and marketing), and connect with stakeholders. This study aims to investigate the institutional performance of dairy farmers and analyze its impact on resources. The research was conducted on May to September 2019 in Pujon sub-district, Malang district, East Java. The respondents were the 174 farmers registered as the member of Tirtasari Kresna Gemilang Joint Business Group (KUB). The data collection utilized Focus Group Discussion (FGD), observation, and survey. The survey was held through interviews and questionnaires with +1 to +5 Likert scale. The variables of this study were institutional performance $(\mathrm{X})$, economic resources $(\mathrm{Y})$, environmental resources $(\mathrm{Y} 2)$, and social resources (Y3). The data was analyzed using the PLS (Partial Least Square) method. The result of the study shows that institutional performance affects economic, environmental, and social resources $31.3 \%, 21.9 \%$, and $45.6 \%$, respectively. This study concluded that the institutional performance of dairy farmers positively and significantly influences the economic and social resources, but insignificantly influences environmental resources.
\end{abstract}

Key words: group dynamics, economic, environmental, social, and resources.

\section{INTRODUCTION}

Farmers institution is an organization that allows cattle farmers to carry out on-farm agribusiness activities, from upstream to downstream, and connect with stakeholders. The institutional role is essential and strategic in realizing cooperation and network with stakeholders as an attempt to build and strengthen the institution. This aims to encourage the growth of the more efficient, effective, and continuous on-farm agribusiness.

The reinforcement of institute for animal husbandry is the means to improve the institutional capacity through business managerial enhancement, development, and business diversification built in a business institution. The institutional reinforcement aims at strengthening society's independency in establishing continuous animal husbandry. The means of animal husbandry empowerment and competitive farmers institutions were done 
through the policy for strengthening farmers institution's capacity to reinforce farmers' institutional economy.

Government Regulation of the Republic of Indonesia Number 6 of 2013 concerning Farmer Empowerment defines farmers empowerment as all means done by the government, provincial government, city/district government, and stakeholders in the field of animal husbandry and animal health to improve self-direction, provide convenience and business progress, and improve the competitiveness and welfare of farmers.

Farmers institution is potential to form and develop its institution, as long as it meets the needs to develop livestock farming business. Anantanyu (2011) explained that the farmers institution in rural areas contribute to the acceleration of farmers' socio-economic development, access to agricultural information, access to capital, infrastructure, and market. The market that established through agriculture and animal husbandry commodity is oligopsony, where traders' offer is more intense and caused the need of institutional empowerment on the level of farmers or breeders (Abubakar et al., 2013).

Amam and Harsita $\left(2019^{\mathrm{a}}\right)$ stated that institutional performance positively and significantly influences farmers' Human Resources (HR). This shows that the better the farmers institutional performance, the better the farmers' HR formed. Amam and Soetriono (2019) stated that institutional performance positively influences the development of livestock farming business. The positive impacts of institutional performance on farmers HR (Amam and Harsita, 2019 ) and livestock farming business development (Amam and Soetriono, 2019), thus, the relevance of this research is to examine the effects of institutional performance on livestock business resources. The institute for animal husbandry that works as the object of this study is Tirtasari Kresna Gemilang, a Joint Business Group (KUB) institutional dairy cattle farmers.

Tirtasari Kresna Gemilang KUB is an institutional dairy farmers located in Malang district, East Java province. Tirtasari Kresna Gemilang KUB is an institution formed in 2017 and incorporated with a Decree of the Minister of Law and Human Rights of the Republic of Indonesia Number AHU 0010084 - AH.01.07. The office is located at Jl. Keramat No. 17 Ngabab, Pujon sub-district. Tirtasari Kresna Gemilang KUB has 174 dairy farmers as the members.

The condition of dairy farmers HR in Tirtasari Kresna Gemilang KUB often intersects with social, politic, and culture interests. This is the impact of Malang district development, especially Pujon sub-district as one of the tourism objects that attract tourists; thus, the use of land and the role of resources division became separate issues in livestock farming business development (Soetriono and Amam, 2020). Ironically, Malang district becomes the National Dairy Farms Area (KPSPN) in accordance with the Decree of the Minister of Agriculture of the Republic of Indonesia Number 43/ Kpts/ PD.010/ 1 of 2015, causes various efforts continue to be made to develop dairy cattle business. One of the means is through maximizing the potential of dairy cattle business resources (Soetriono et al., 2019). Proyono and Priyanti (2015) stated that the establishment of dairy cattle development areas was carried out in relation to the national dairy industry development planning. 
Resources is important in the development of livestock farming business (Amam et al., 2019 ; Amam et al., 2019 ; Amam et al., 2019 $)$. Amam et al. (2019 $)$ explain that farmers HR and farmers accessibility on economic resources, environmental resources, and social resources influence the development of livestock business by $34,1 \%$, thus, resources play an important role in livestock business development (Amam and Soetriono, 2020) and farmers HR (Amam et al., 2019f). Amam et al. (2019²) also states that the livestock business resources are financial resources, technology resources, and physical resources (Amam et al., 2019'; Amam et al., 2020 $)$. Livestock business resources also consist of economic, environmental, and social resources (Amam et al., 2020).

This study aims to investigate the institutional performance of dairy farmers and analyze the effects on the resources. The resources included economic resources, environmental resources, and social resources. The resources were part of the three pillars of livestock business. Amam and Harsita $\left(2019^{c}\right)$ states that there are three pillars in livestock business which are breeding, feeding, and management. The research was conducted at Tirtasari Kresna Gemilang KUB, Malang district. The novelty of this research is to find the accessibility of dairy farmers resources influenced by the institutional performance of Tirtasari Kresna Gemilang KUB dairy farmers. Siswijono et al. (2014) stated that the development of farmers institution needs to consider the economic, technical, and social aspects.

\section{METHODS}

This study used expost facto research approach. The data were collected from May to September 2019 at Pujon sub-district, Malang district, East Java. The research location was determined through purposive sampling with the consideration that Malang District is one of the National Dairy Farm Area (KPSPN) in accordance with the Decree of the Minister of Agriculture of the Republic of Indonesia Number 43/ Kpts/ PD.010/ 1 of 2015. The respondents were the members of Tirtasari Kresna Gemilang Joint Business Group (KUB). The number of the respondents were 174 dairy farmers (total sampling). The data were collected through Focus Group Discussion (FGD), observation, and survey. The survey was done by distributing questionnaires and conducting interviews. The questionnaires were +1 to +5 likert scale. The scale +1 showed that the respondents strongly disagree, scale +2 showed that the respondents disagree, scale +3 told that the respondents were neutral, scale +4 indicated that the respondents agree, and scale +5 indicated that the respondents strongly agree. The research variables consisted of institutional performance $(\mathrm{X})$, economic resources $\left(\mathrm{Y}_{1}\right)$, environmental resources $\left(\mathrm{Y}_{2}\right)$, and social resources $\left(\mathrm{Y}_{3}\right)$. The $\mathrm{X}$ was an exogenous variable, while $\mathrm{Y}$ was endogenous variable. The indicators of each variable are defined in Table 1.

Amam et al. (2019f) states that institutional performance of dairy farmers is about the good and poor performance of the farmer institution. Economic resources are the resources accessible by the farmers closely related to farmers' current economic condition. Environmental resources are resources accessible by the farmers closely related to livestock condition and issues. Social resources are resources accessible by the farmers closely related to farmers' social relation. 
TABLE 1. RESEARCH VARIABLES AND INDICATORS

\begin{tabular}{|c|c|c|}
\hline Variable & Indicator & Notation \\
\hline Institutional performance & group tools & $X_{1.1}$ \\
\hline \multirow[t]{5}{*}{$(X)$} & group goals achievement & $X_{1.2}$ \\
\hline & group functions and task & $X_{1.3}$ \\
\hline & group structure & $X_{1.4}$ \\
\hline & group harmony & $X_{1.5}$ \\
\hline & institutional from & $X_{1.6}$ \\
\hline \multirow[t]{8}{*}{ Economic resources $\left(Y_{1}\right)$} & formal education of farmers & $Y_{1.1}$ \\
\hline & informal education of farmers & $Y_{1.2}$ \\
\hline & family labor involvement level & $Y_{1.3}$ \\
\hline & family health status & $Y_{1.4}$ \\
\hline & family nutrition consumption & $Y_{1.5}$ \\
\hline & house comfort level & $Y_{1.6}$ \\
\hline & opportunity to use spare time for recreation & $Y_{1.7}$ \\
\hline & farmers' credibility level & $Y_{1.8}$ \\
\hline \multirow{6}{*}{$\begin{array}{l}\text { Environmental resources } \\
\left(Y_{2}\right)\end{array}$} & air pollution level & $Y_{2.1}$ \\
\hline & soil contamination level & $Y_{2.2}$ \\
\hline & water pollution level & $Y_{2.3}$ \\
\hline & noise pollution level & $Y_{2.4}$ \\
\hline & utilization of cow dung as fertilizer & $Y_{2.5}$ \\
\hline & utilization of agricultural waste as animal feed & $Y_{2.6}$ \\
\hline \multirow[t]{9}{*}{ Social resources $\left(Y_{3}\right)$} & farmers' role in community organization & $Y_{3.1}$ \\
\hline & coordination relations with other farmers & $Y_{3.2}$ \\
\hline & relations with village officials & $Y_{3.3}$ \\
\hline & relations with livestock health workers & $Y_{3.4}$ \\
\hline & relations with animal husbandry department & $Y_{3.5}$ \\
\hline & relations with animal feed companies & $Y_{3.6}$ \\
\hline & relations with field counselors & $Y_{3.7}$ \\
\hline & relations with financial institutions & $Y_{3.8}$ \\
\hline & relations with dairy processing industry (IPS) & $Y_{3.9}$ \\
\hline
\end{tabular}

Based on the description of research variables and indicators in Table 1, the relationship model between variables is shown in Figure 1.

The hypothesis built based on Figure 1 was that the institutional performance of dairy farmers positively influenced economic, environmental, and social resources. The data analysis utilized PLS (Partial Least Square) method with SmartPLS2.0. tools. PLS method generally consists of two types of test i.e. outer model and inner model. Outer model test is the evaluation of measurement model and weighting schemes. Outer model test consists of outer loading value (indicator test), AVE (Average Variance Extracted) value, CA (Cronbach's Alpha) value, and R2 value. Inner model test is the evaluation of structural model or influence test of exogenous variables toward endogenous variables. Inner model test consists of coefficient of determination value, $t$-statistic value, and parameter coefficient value. 


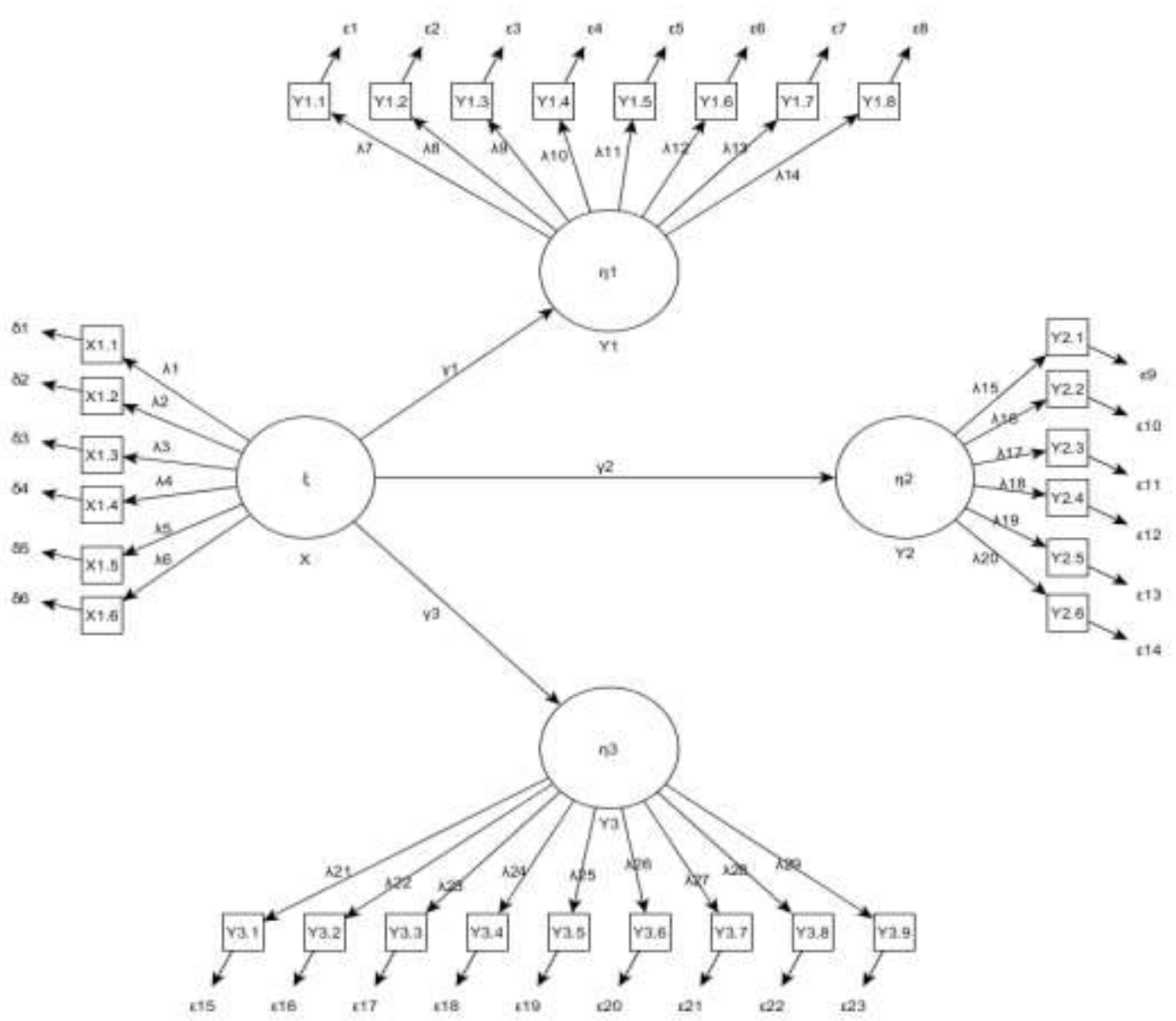

FIGURE 1. RELATIONSHIP MODEL BETWEEN VARIABLES

Based on the description of variables and indicators in Table 1 and the relationship model between variables in Figure 1, the mathematical equation obtained is as follows:

Exogenous latent variables $(\mathrm{X}) /$ reflective

$\begin{array}{lll}X_{1.1}=\left(\lambda_{1} \xi_{1}\right)+\delta_{1} & X_{1.4}=\left(\lambda_{4} \xi_{1}\right)+\delta_{4} \\ X_{1.2}=\left(\lambda_{2} \xi_{1}\right)+\delta_{2} & X_{1.5}=\left(\lambda_{5} \xi_{1}\right)+\delta_{5} \\ X_{1.3}=\left(\lambda_{3} \xi_{1}\right)+\delta_{3} & X_{1.6}=\left(\lambda_{6} \xi_{1}\right)+\delta_{6}\end{array}$

Endogenous latent variables $\left(\mathrm{Y}_{1}\right) /$ reflective

$\begin{aligned} Y_{1.1} & =\left(\lambda_{7} \eta_{1}\right)+\varepsilon_{1} & Y_{1.5} & =\left(\lambda_{11} \eta_{1}\right)+\varepsilon_{5} \\ Y_{1.2} & =\left(\lambda_{8} \eta_{1}\right)+\varepsilon_{2} & Y_{1.6} & =\left(\lambda_{12} \eta_{1}\right)+\varepsilon_{6} \\ Y_{1.3} & =\left(\lambda_{9} \eta_{1}\right)+\varepsilon_{3} & Y_{1.5} & =\left(\lambda_{13} \eta_{1}\right)+\varepsilon_{7} \\ Y_{1.4} & =\left(\lambda_{10} \eta_{1}\right)+\varepsilon_{4} & Y_{1.6} & =\left(\lambda_{14} \eta_{1}\right)+\varepsilon_{8}\end{aligned}$

Endogenous latent variables $\left(\mathrm{Y}_{2}\right) /$ reflective

$\begin{array}{llll}Y_{2.1} & =\left(\lambda_{15} \eta_{2}\right)+\varepsilon_{9} & Y_{2.4} & =\left(\lambda_{18} \eta_{2}\right)+\varepsilon_{12} \\ Y_{2.2} & =\left(\lambda_{16} \eta_{2}\right)+\varepsilon_{10} & Y_{2.5} & =\left(\lambda_{19} \eta_{2}\right)+\varepsilon_{13} \\ Y_{2.3} & =\left(\lambda_{17} \eta_{2}\right)+\varepsilon_{11} & Y_{2.6} & =\left(\lambda_{20} \eta_{2}\right)+\varepsilon_{14}\end{array}$

Endogenous latent variables $\left(\mathrm{Y}_{3}\right) /$ reflective

\begin{tabular}{|c|c|c|c|}
\hline$=\left(\lambda_{21} \eta_{3}\right)+\varepsilon_{15}$ & $Y_{3.4}$ & $=\left(\lambda_{24} \eta_{3}\right)+\varepsilon_{18}$ & $Y_{3.7}$ \\
\hline$=\left(\lambda_{22} \eta_{3}\right)+\varepsilon_{16}$ & $Y_{3.5}$ & $=\left(\lambda_{25} \eta_{3}\right)+\varepsilon_{19}$ & $Y_{3.8}$ \\
\hline$=\left(\lambda_{23} \eta_{3}\right)+\varepsilon_{17}$ & $Y_{3.6}$ & $=\left(\lambda_{26} \eta_{3}\right)+\varepsilon_{20}$ & $Y_{3.9}$ \\
\hline
\end{tabular}




\section{RESULT AND DISCUSSIONS}

The research indicators were tested with PLS (Partial Least Square) method. The results of indicator test were the outer loading value on outer model system. The indicators considered valid and qualified were those with $>0.500$ outer loading value. Indicators with $<0.500$ outer loading value were considered invalid and not qualified, thus, they needed to be eliminated from model. The indicator test results are defined in Table 2.

TABLE 2. INDICATOR TEST RESULTS

\begin{tabular}{|c|c|c|c|c|c|}
\hline Indicator & $X$ & $Y_{1}$ & $Y_{2}$ & $Y_{3}$ & Result \\
\hline$X_{1.1}$ & 0.912 & & & & valid \\
\hline$X_{1.2}$ & 0.756 & & & & valid \\
\hline$X_{1.3}$ & 0.884 & & & & valid \\
\hline$X_{1.4}$ & 0.526 & & & & valid \\
\hline$X_{1.5}$ & 0.714 & & & & valid \\
\hline$X_{1.6}$ & 0.845 & & & & valid \\
\hline$Y_{1.2}$ & & 0.964 & & & valid \\
\hline$Y_{1.3}$ & & 0.816 & & & valid \\
\hline$Y_{1.4}$ & & 0.649 & & & valid \\
\hline$Y_{1.5}$ & & 0.552 & & & valid \\
\hline$Y_{1.6}$ & & 0.533 & & & valid \\
\hline$Y_{1.7}$ & & 0.547 & & & valid \\
\hline$Y_{1.8}$ & & 0.747 & & & valid \\
\hline$Y_{2.1}$ & & & 0.678 & & valid \\
\hline$Y_{2.4}$ & & & 0.512 & & valid \\
\hline$Y_{2.5}$ & & & 0.834 & & valid \\
\hline$Y_{2.6}$ & & & 0.819 & & valid \\
\hline$Y_{3.1}$ & & & & 0.953 & valid \\
\hline$Y_{3.2}$ & & & & 0.826 & valid \\
\hline$Y_{3.3}$ & & & & 0.612 & valid \\
\hline$Y_{3.4}$ & & & & 0.532 & valid \\
\hline$Y_{3.6}$ & & & & 0.674 & valid \\
\hline$Y_{3.8}$ & & & & 0.889 & valid \\
\hline$Y_{3.9}$ & & & & 0.825 & valid \\
\hline
\end{tabular}

Description: Outer Loading Value After Eliminating Invalid Indicators

Outer model system assembled criteria including AVE (Average Variance Extracted) value, CA (Cronbach's Alpha) value, and R Square value. The results of outer model test are defined in Table 3.

TABLE 3. RESULTS OF OUTER MODEL TEST

\begin{tabular}{lcccc}
\hline Variable & Notation & AVE & CA & $R^{2}$ \\
\hline Institutional performance & $X$ & 0.844 & 0.873 & \\
Economic resources & $Y_{1}$ & 0.825 & 0.848 & 0.313 \\
Environmental resources & $Y_{2}$ & 0.723 & 0.765 & 0.219 \\
Social resources & $Y_{3}$ & 0.938 & 0.864 & 0.456 \\
\hline
\end{tabular}

Model test for influence or structural test consists of coefficient of determination value, t-statistic value, and parameter coefficient value. The results of inner model test are defined in Table 4. 
TABLE 4. RESULTS OF INNER MODEL TEST

\begin{tabular}{rcc}
\hline \multicolumn{1}{l}{ Test } & Value & Description \\
\hline Coefficient of determination $\left(R^{2}\right)$ & & \\
a. Economic resources & 0.313 & \\
b. Environmental resources & 0.219 & \\
c. Social resources & 0.456 & \\
t-statistic & & \\
a. $X \rightarrow Y_{1}$ & 2.906 & significant \\
b. $X \rightarrow Y_{2}$ & 1.615 & insignificant \\
c. $X \rightarrow Y_{3}$ & 3.854 & significant \\
Parameter coefficient & & \\
a. $X \rightarrow Y_{1}$ & 0.215 & positive influence \\
b. $X \rightarrow Y_{2}$ & 0.188 & positive influence \\
c. $X \rightarrow Y_{3}$ & 0.347 & positive influence \\
\hline t table: 1.653 & &
\end{tabular}

\section{The Influence of Institutional Performance on Economic Resources}

The economic resources of dairy farmers are influenced by the institutional performance by $31,3 \%$. Institutional performance positively and significantly influences economic resources by $0.215(2.906>1.653)$. It shows that dairy farmers institution in Tirtasari Kresna Gemilang Joint Business Group (KUB) positively influences the economic resources of dairy farmers. The better the institutional performance, the bigger the access of farmers to economic resources.

The institutional performance of Tirtasari Kresna Gemilang KUB positively influences economic resources of dairy farmers. The excellent institutional performances are group facilities, group achievement goals, group function and group tasks, group/organizational structure, harmony among dairy farmers, dairy farmers institutional model that is considered able to improve farmers' welfare. According to Mauludin et al. (2012), institutional role as a production unit needs to describe the group function in encouraging efficient economic scale achievement in producing results.

Such institutional conditions can positively influence the farmers' accessibility to economic resources. Farmers can notice the impacts due to economic improvement. Dairy farmers' economic improvement is also supported by tourism development in Malang district, especially Pujon sub-district. Tourism development allows the farmers' income to increase because one of the market orientation of dairy processing industry (IPS) in home industry (IRT) scale is tourists.

However, tourism also negatively impacts the development of cattle business. It is due to the distribution of resources role such as land use. The empty lands that were once planted with forage were turned into parking lot and street vendor stalls. This condition inhibits the availability of forage.

Generally, the role of Tirtasari Kresna Gemilang KUB has accommodate the dairy farmers. Hidayanto et al. (2009) states that institutional development is necessary due to several factors: a) many agricultural problems can be solved through farmers institutions, b) knowledge and technology routine sharing, c) establishing competitive farmers with a more open economic structure, and d) strengthening cooperation in the use of resources to be more efficient. 


\section{The Influence of Institutional Performance on Environmental Resources}

The environmental resources of dairy farmers are influenced by the instututional performance of dairy farmers by $21,9 \%$. Institutional performance positively but insignificantly influences environmental resources by $0.188(1.615<1.653)$. It shows that dairy farmers institution in Tirtasari Kresna Gemilang KUB (Joint Business Group) positively influences the environmental resources but the farmers have not received the benefits yet. The KUB performance has not reduced the level of air, water, and soil pollution, as well as noise pollution as the impacts of livestock business.

The institutional performance of Tirtasari Kresna Gemilang KUB shows a positive impact on dairy farmers' environmental resources. The good institutional performances are group facilities, group achievement goals, group function and group tasks, group/organizational structure, harmony among dairy farmers, dairy farmers institutional model that is considered able to improve farmers' welfare.

Such institutional conditions positively influences the farmers' accessibility to environmental resources. Farmers gain the benefits due to the improvement of environmental resources. One of the qualities is shown by the level of air and noise pollution. Pollution commonly happens to the environment of livestock business. One of the efforts to suppress the pollution level is through utilizing the cow dung. Cow dung is utilized as the raw material for biogas and organic fertilizer for agriculture.

The environmental quality can also be enhanced by utilizing agricultural waste as animal feed. The agricultural waste commonly used as animal feed are rice straw and corn strover. Livestock business with forage land basis has increasingly limited capacity. The tourism development in Malang district worsens this condition. The implementation of Integrated Crop-Livestock System is one of the efforts to unravel the problems. Saptana and Ilham (2015) state that the integration of crops and livestock can increase the financial resources of farmers.

Regarding the environmental resources, Suardi et al. (2016) states that the attempt to maintain agricultural land needs to be done thoroughly. This is closely related to the utilization of agricultural waste as animal feed. Hilmi et al. (2016) explains that the main barrier in forage provision is the inconsistent production throughout the year. During rainy season the forage production is abundant, while in the dry season the production level becomes very low.

\section{The Influence of Institutional Performance on Social Resources}

The social resources of dairy farmers is influenced by the institutional performance of dairy farmers by $45,6 \%$. Institutional performance positively and significantly influences social resources by $0.347(3.854>1.653)$. It indicates that dairy farmers in Tirtasari Kresna Gemilang KUB (Joint Business Group) positively influences the social resources. The better the institutional performance, the better the access for farmers to social resources.

The institutional performance of Tirtasari Kresna Gemilang KUB shows positive impacts on the social resources of dairy farmers. The excellent institutional performances are group facilities, group achievement goals, group function and group tasks, group/organizational structure, harmony among dairy farmers, dairy farmers institutional model that is considered able to improve farmers' social relation. 
Such institutional conditions positively influence the farmers' accessibility to social resources. The benefits are gained as the effects of improved social relation. It indicates that Tirtasari Kresna Gemilang has accommodate dairy farmers in Malang district. The access for dairy farmers to social resources allows them to have opportunities to capital loan through financial institutions. Capital has become a main barrier in the development of livestock business. Amam et al. (2019a) states that livestock business development is influenced by farmers' access to resources. The access to market information on social resources is quite limited, therefore it contributes to the weakening of farmers' offer (Rahayu and Kartika, 2015). Irawati and Yantu (2015) state that agricultural farmers groups makes it easier for farmer group members to carry out farming activities, including access to information market.

The role of farmers institution may also be in the form of information access such as assistance from the government, credit loans, forage, livestock production facilities, as well as livestock and dairy marketing (Siswoyo et al., 2013), for an effective and efficient livestock business. According to Suresti and Wati (2012), livestock business is integration of production and financial management, production manages input and output. The higher the profit, the more effective and efficient the business is, thus, farmers' offer will improve and create competence in the market to achieve business goals.

\section{CONCLUSIONS}

Institutional performance influences the economic, environment, and social resources by $31.3 \%, 21.9 \%$, and $45.6 \%$, respectively. Institutional performance of dairy farmers positively and significantly influences the economic and social resources, but insignificantly influences environmental resources.

\section{ACKNOWLEDGEMENTS}

This paper is the outcome of long and continuous research that involves many parties. They deserve an appreciation from the authors. The authors would like to thank: a) LP2M (Institute of Research and Community Service) of Universitas Jember; b) KeRis (Research Group) Agribusiness and Agroindustry of Animal Husbandry (A2P) KeRis; c) Students of Animal Husbandry Study Program, Faculty of Agriculture, Universitas Jember who were involved in the 2019-2021 Research Project; and d) dairy farmers in Tirtasari Kresna Gemilang KUB Malang District.

\section{REFERENCES}

Abubakar, I., Yantu, M. R., \& Asih, D. N. (2013). Kinerja Kelembagaan Pemasaran Kakao Biji Tingkat Petani Perdesaan Sulawesi Tengah: Kasus Desa Ampibabo Kecamatan Ampibabo Kabupaten Parigi Moutong. e-J. Agrotekbisnis.1(1), 74-80.

Amam, Fanani, Z., Hartono, B., \& Nugroho, B. A. (2019a). Broiler Livestock Business Based on Partnership Cooperation in Indonesia: The Assessment of Opportunities and Business Developments. International Journal of Entreneurship. 23(4), 1-11.

Amam, Fanani, Z., Hartono, B., \& Nugroho, B. A. (2019b). Identification of the Resources in the System of Broiler Farming Business. Jurnal Ilmu Ternak dan Veteriner. 24(3), 135-142. DOI: http://dx.doi.org/10.14334/jitv.v24i3.1927. 
Amam, Fanani, Z., Hartono, B., \& Nugroho, B. A. (2019c). Pengembangan Usaha Ternak Ayam Pedaging Sistem Kemitraan Bagi Hasil Berdasarkan Aksesibilitas Peternak Terhadap Sumber Daya. Jurnal Ilmu dan Teknologi Peternakan Tropis. 6(2), 146-153. DOI: http://dx.doi.org/10.33772/jitro.v6i2.5578.

Amam, Fanani, Z., Hartono, B., \& Nugroho, B. A. (2019d). Usaha Ternak Ayam Pedaging Sistem Kemitraan Pola Dagang Umum: Pemetaan Sumber Daya dan Model Pengembangan. Sains Peternakan: Jurnal Penelitian Ilmu Peternakan. 17(2). 5-11. DOI: https://doi.org/10.20961/sainspet.v17i2.26892.

Amam \& Harsita, P. A. (2019a). Aspek Kerentanan Usaha Ternak Sapi Perah di Kabupaten Malang. Agrimor: Jurnal Agribisnis Lahan Kering. 4(1), 26-28. DOI: https://doi.org/10.32938/ag.v4i2.663.

Amam \& Harsita, P. A. (2019b). Efek Domino Performa Kelembagaan, Aspek Risiko, dan Pengembangan Usaha Terhadap SDM Peternak Sapi Perah. Sains Peternakan: Jurnal Penelitian Ilmu Peternakan. 17(1), 5-11. DOI: https://doi.org/10.20961/sainspet.v17i1.24266.

Amam \& Harsita, P. A. (2019c). Tiga Pilar Usaha Ternak: Breeding, Feeding, and Management. 14(4), 431-439. DOI: https://doi.org/10.31186/jspi.id.14.4.431-439.

Amam, Jadmiko, M. W., Harsita, P. A., \& Yulianto, R. (2019e). Internal Resources of Dairy Cattle Farming Business and their Effect on Institutional Performance and Business Development. Animal Production. 21(3), 157-166. DOI: http://doi.org/10.20884/1.jap.2019.21.3.738.

Amam, Jadmiko, M. W., Harsita, P. A., \& Poerwoko, M. S. (2019f). Model Pengembangan Usaha Ternak Sapi Perah Berdasarkan Faktor Aksesibilitas Sumber Daya. Jurnal Sain Peternakan Indonesia. 14(1), 61-69. DOI: https://doi.org/10.31186/jspi.id.14.1.61-69.

Amam, Jadmiko, M. W., Harsita, P. A., Widodo, N., \& Poerwoko, M. S. (2019g). Sumber Daya Internal Peternak Sapi Perah dan Pengaruhnya Terhadap Dinamika Kelompok dan Konteks Kerentanan. Jurnal Ilmiah Peternakan Terpadu. 7(1), 192-200. DOI: http://dx.doi.org/10.23960/jipt.v7i1.p192-200.

Amam, Jadmiko, M. W., Harsita, P. A., Yulianto, R., Widodo, N., Soetriono, \& Poerwoko, M. S. (2020a). Usaha Ternak Sapi Perah di Kelompok Usaha Bersama (KUB) Tirtasari Kresna Gemilang: Identifikasi Sumber Daya dan Kajian Aspek Kerentanan. Jurnal Ilmu Peternakan dan Veteriner Tropis. 10(1), 77-85. DOI: https://doi.org/10.30862/jipvet.v10i1.

Amam, Yulianto, R., Widodo, N., \& Romadhona, S. (2020b). Pengaruh Aspek Kerentanan terhadap Aksesibilitas Sumber Daya Usaha Ternak Sapi Potong. Livestock and Animal Research. 18(2), 160-170. DOI: https://doi.org/10.20961/lar.v18i2.42955.

Amam \& Soetriono. (2019). Evaluasi Performa Kelembagaan Berdasarkan Aspek Risiko Bisnis dan Konteks Kerentanan. Jurnal Ilmu dan Teknologi Peternakan Tropis. 5(3), 813. DOI: http://dx.doi.org/10.33772/jitro.v6i1.5391.

Amam \& Soetriono (2020). Peranan Sumber Daya terhadap SDM Peternak dan Pengembangan Usaha Ternak Sapi Perah di Kawasan Peternakan Sapi Perah Nasional (KPSPN). Jurnal Peternakan Indonesia. 22(1), 1-10. DOI: https://doi.org/10.25077/jpi.22.1.1-10.2020. 
Anantanyu, S. (2011). Kelembagaan Petani: Peran dan Strategi Pengembangan Kapasitasnya. SEPA, 7(2), 102-109.

Hidayanto, M., Supiandi, S., Yahya, S., \& Amien, L. I. (2009). Analisis Keberlanjutan Perkebunan Kakao Rakyat di Kawasan Perbatasan Pulau Sebatik, Kabupaten Nunukan, Provinsi Kalimantan Timur. Jurnal Agro Ekonomi. 27(2), 213-229.

Hilmi, M., Haq, E. S. \& Panduardi, F. (2016). IBM Pemberdayaan Kelompok Ternak Kambing Etawa Melalui Pelatihan dan Pendampingan Dalam Produksi Silase Sebagai Pakan Alternatif di Desa Wongsorejo. J-Dinamika: Jurnal Pengabdian kepada Masyarakat. 1(2), 70-76.

Irawati, E. \& Yantu, M. R. (2015). Kinerja Kelompok Tani dalam Menunjang Pendapatan Usaha Tani Padi Sawah di Desa Sidera Kecamatan Sigi Biromaru Kabupaten Sigi. E. J. Agrotekbis. 3(2), 206-211.

Mauludin, M. A., Winaryanto, S., \& Alim, S. (2012). Peran Kelompok dalam Mengembangkan Keberdayaan Peternak Sapi Potong. Jurnal Ilmu Ternak. 12(1), 1-8.

Priyono \& Priyanti, A. (2015). Penguatan Kelembagaan Koperasi Susu melalui Pendekatan Pengembangan Kawasan Peternakan Nasional. Jurnal Wartazoa. 25(2), 85-94. DOI: http://dx.doi.org/10.14334/wartazoa.v25i2.1145.

Rahayu, R. E. \& Kartika, L. (2015). Analisis Kelembagaan dan Strategi Peningkatan Daya Saing Komoditas Kentang di Kabupaten Bankarnegara, Jawa Tengah. Jurnal Ilmu Pertanian Indonesia. 20(2), 150-157.

Saptana \& Ilham, S. (2015). Pengembangan Sistem Integrasi Tanaman Tebu-Sapi Potong di Jawa Timur. Jurnal Analisis Kebijakan Pertanian. 13(2), 147-165.

Siswijono, S. B., Nurgiartiningsih, V. M. A., \& Hermanto. (2014). Pengembangan Model Kelembagaan Konservasi Sapi Madura. Jurnal Ilmu-ilmu Peternakan. 24(1), 33-38.

Siswoyo, H., Setyono, D. J., \& Fuah, A. M. (2013). Analisis Kelembagaan dan Peranannya terhadap Pendapatan Peternak di Kelompok Tani Simpay Tampomas Kabupaten Sumedang Provinsi Jawa Barat. Jurnal Ilmu Produksi dan Teknologi Hasil Peternakan. 1(3), 172-178.

Soetriono \& Amam. (2020). The Performance of Institutional of Dairy Cattle Farmers and Their Effect on Financial, Technological, and Physical Resources. Jurnal Ilmu-ilmu Peternakan. 30(2), 128-137. DOI: https://doi.org/10.21776/ub.jiip.2020.030.02.05.

Soetriono, Soejono, D., Zahrosa, D. B., Maharani, A. D., \& Amam. Strategi Pengembangan dan Diversifikaso Sapi Potong di Jawa Timur. Jurnal Ilmu dan Teknologi Peternakan Tropis. 6(2), 138-145. DOI: http://dx.doi.org/10.33772/jitro.v6i2.5571.

Suardi, I. D. P. O., Darmawan, D. P., \& Sarjana, I. D. G. R. (2016). Potensi dan Peran Kelembagaan Pertanian dalam Perlingdungan Lahan Pertanian Pangan di Provinsi Bali. Jurnal Manajemen Agribisnis. 4(1), 1-9.

Suresti, A. \& Wati, R. (2012). Strategi Pengembangan Usaha Peternakan Sapi Potong di Kabupaten Pesisir Selatan. Jurnal Peternakan Indonesia. 14(1), 249-262. 